\title{
Sugarcane Flower-Control Studies With Paraquat, Gibberellic Acid, and Sodium Meta-Silicate ${ }^{1}$
}

\author{
Alex G. Alexander, R. Montalvo-Zapata, Gene L. Spain, and Ashok Kumar ${ }^{2}$
}

\section{INTRODUCTION}

Although the flowering of sugarcane is essential for breeding new varieties, uncontrolled flowering in commercial acreages presents a serious problem for sugar growers. Plants forming a flower do not produce a desirable stalk with regard to percent fiber and juice quality $(16,17,25,35)$. Consequently, major efforts have been made to prevent flowering by use of chemicals applied to the foliage. Some success has been reported with compounds such as maleic hydrazide, CMU, Diquat, Cycocel and Phosphor $(21,22,26)$.

An important limitation of chemicals having anti-flowering activity is their tendency to restrict sugar-forming mechanisms. An example of this is Diquat, a quaternary ammonium compound which disrupts photosynthesis and leads to major sucrose decline $(5,7)$. Humbert et al. (28) has suggested that these effects are relatively temporary and sucrose losses are more than made good by the flowering control thereby achieved. Heinz (27) expressed a similar view with respect to flowering control in Hawaii. Paraquat, another quaternary ammonium compound, has shown promise as a flower-controlling agent, but again a major sucrose decline is risked owing to its adverse photosynthetic and enzyme effects $(2,5)$. Controlledillumination studies have shown that Paraquat applied to cane leaves causes a sucrose decline almost identical to that produced by continuous darkness (8). Since many weeks will pass before the dead or injured foliage is replaced by a new green top, the ensuing restrictions against growth and sugar production constitute a serious expense for the grower. The same will likcly be true of any chemical whose flower-controlling capability rests upon destruction of the green-leaf area. With these considerations in mind, research was initiated in Puerto Rico with the objective of flowering prevention by means of chemically-altered physiology rather than by outright destruction of essential plant organs.

A clue to better means of flower control lies in the extreme sensitivity of the floral-induction process. Photoperiod $(29,34,38)$, solar energy $(13,37)$, temperature $(12,14,20,23)$ and water regime $(12,31,36)$, all bear heavily

1 Manuscript submitted to Editorial Board September 16, 1971.

${ }^{2}$ Plant Physiologist, Assistant Chemist, Associate Agronomist, and Assistant Biochemist, respectively, Agricultural Experiment Station, Mayagüez Campus, University of Puerto Rico, Río Piedras, P.R. 
upon the successful initiation of the flower primordia. The period of actual initiation is critically short. Sugarcane may initiate primordia from Scptember 1 to September 20 in Hawaii (14), and from about September 3 to October 6 in Puerto Rico (16), but individual varieties have discrete and highly-restricted periods within these intervals. Coleman $(19,22,24)$ has described distinct flowering activity by leaf and spindle tissues. Removal of the spindle during differentiation reduced the percentage of flowers. Chu (32) found that removal of the spindle severely retarded flowering while leaf removal had little effect. ${ }^{3}$

A series of flower-control studies have been initiated in Puerto Rico based on chemical control of physiological changes in leaf and meristematic tissues. The present paper summarizes initial experiments in which Paraquat, gibberellic acid (GA), and sodium meta-silicate (Si) were tested for anti-flowering activity. Puraquat is highly toxic against green-leaf tissues where part of the flowering stimulus is thought to originate. GA is a growthpromoting hormone possibly capable of preserving a vegetative meristem throughout the critical period of floral initiation. Si was tested as a possible "buffering" agent against both natural and chemically-induced changes in physiological activity.

\section{EXPERIMENTAL PROCEDURE}

Two field experiments were conducted at Central Mercedita, near Ponce, employing the heavy-flowering variety C.P. 52-43. Plots having dimensions of 20 feet by 20 feet were staked out on August 22 in a 6-month old, firstratoon crop in which heavy floral induction was anticipated around September 10. This crop was in ideal condition for experimental purposes. Grown on a heavy clay soil with supplemental irrigation, the stand was relatively uniform as to plant size and distribution. There was no lodging, the variety having a persistently upright growth habit. It was possible to move freely between the rows with ladders and spray equipment. The variety also features a nearly glabrous leaf sheath and margin which affords a relatively comfortable plant with which to work.

Each experiment received the following treatments in aqueous solution: (a) The control, consisting only of water and the wetting agent Tween 20; (b) sodium meta-silicate ( $\mathrm{Si}$ ) equivalent to 500 p.p.m. of elemental $\mathrm{Si}$; (c)

It is believed that a flowering substance or substances, possibly phytochrome, is formed in the leaves by specific light reactions, and is stabilized in the leaves by specific dark reactions (24). The material is then translocated to the meristematic area where floral induction occurs following a critical period of accumulation and, possibly, the synthesis of another substance. The effectiveness of spindle removal as compared to leaf removal enhances the prospect of a rate-limiting substance originating in the spindle, and suggests that the antiflowering action of Diquat may occur in the spindle rather than in mature leaf blades. 
gibberellic acid (GA) equivalent to 0.01 percent of the pure acid; and (d) $\mathrm{GA}$ combined with $\mathrm{Si}$. The four treatments were arranged in a randomized complete block design with six replicates. A guard area consisting of 16 rows, about 84 feet in width, separated the two experiments. The second experiment received Paraquat superimposed over identical GA and Si treatments. Paraquat was applied by aircraft at the rate of 0.5 pint per acre in a volume of water equivalent to 8 gallons per acre.

The GA and Si treatments were applied on August 22 and repeated on August 29. Employing knapsack sprayers and solution volumes equivalent to 300 gallons per acre, all canes were treated with a thoroughness impractical to duplicate by aerial means. ${ }^{4}$ The sprayer operator first worked from the ground, treating the stalks and as much of the foliage as he could reach from each side of the row. He then mounted an 8-foot aluminum stepladder and treated the tops, an assistant periodically moving the ladder to facilitate coverage. A single Paraquat treatment was given 3 days after the $\mathrm{GA}$ and Si applications were complete.

Samples were harvested for growth and sugar analyses at 20,55, 96 and 117 days after initial treatment. These consisted of four uniform stalks per replicate for the first three harvests and 10 stalks per replicate at the final harvest. Total fresh weights, stalk weights, and internode lengths were recorded within a few hours after cutting the cane. Stalks were milled for Brix and polarization analyses within 30 hours of harvest. From the first three harvests samples of leaves +1 to +4 and immature storage tissue were also taken for sucrose analyses. These were quick-frozen in a mixture of dry ice and acetone and transferred to the main station in an ice chest packed with dry ice. The samples were lyophilized, ground to pass a 60 -mesh screen, and stored at $-5^{\circ}$ to $-10^{\circ} \mathrm{C}$. until needed for extraction. Clarified juice was analyzed for sucrose by the method of Cardini et al. (15).

Flower counts were taken on December 27, 97 days after initial treatment applications. The total cane population of each plot was also recorded at this time and flowering was computed on a percentage basis. All replicated data were analyzed statistically by the Duncan new multiple range test. In some instances replicate samples had to be combined and their mean values are treated empirically in the text.

- Two fundamental problems of chemical flowering control are, first, the economics and agronomics of material application, and second, the physiological limitations of the chemicals' action. Our main concern was with the second problem. Above all we wished to make certain that those treatments which failed to give flower control did so because of physiological inability rather than because of inadequate coverage, as could well be the cause of failure when chemicals are tested with aerial equipment or at low gallonage. 


\section{RESULTS AND DISCUSSION}

Within 3 days after treatment plants sprayed with Paraquat exhibited typical desiccation symptoms in the upper green-leaf areas. Tissues directly contacted by the aerial spray were severely injured but this did not usually: include the entire blade. Older leaves and those generally less exposed to the acrial spray displayed less severe injury symptoms such as the isolated patches or blotches of reddish-brown discoloration typical of very low Paraquat levels $(2,5)$. The Paraquat was applied with excellent precision and only traces of the chemical's symptoms were found in the adjoining non-Paraquat plots.

Within 20 days after initial GA application the previously uniform stand began to develop a wavy, uneven surface as viewed from above. Presumably, this resulted from GA-treated plants elongating more rapidly than non-treated ones. The unevenness gradually diminished so that no consist-

TABLE 1.-Effects of foliar Paraqual, GA, and Si on flower production by the sugarcane variety C.P. $68-491$

\begin{tabular}{ccccccc}
\hline \multirow{2}{*}{$\begin{array}{c}\text { Experiment } \\
\text { Number }\end{array}$} & $\begin{array}{c}\text { Paraquat } \\
\text { (pints/acre) }\end{array}$ & \multicolumn{4}{c}{ Percentage of plants with flowers for treatment- } & \multirow{2}{*}{ Mean } \\
\cline { 3 - 6 } & Control & $\begin{array}{c}\text { Si } \\
(500 \text { p.p.m.) }\end{array}$ & $\begin{array}{c}\text { GA } \\
(0.01 \%)\end{array}$ & $\begin{array}{c}\text { Si plus } \\
\text { GA }\end{array}$ & \\
\hline 1 & 0 & 26.6 & 26.7 & $0.02^{* *}$ & $14.8^{*}$ & 17.0 \\
2 & 0.5 & 8.9 & 9.8 & 0.01 & 0.02 & 4.7 \\
\hline
\end{tabular}

1 Each figure represents the mean of six replicates.

* Deviation from control is significant at the 5-percent level.

** Deviation from control is significant at the 1-percent level.

ent sized differences could be detected by visual inspection at the final harvest.

\section{FLOWER CONTROL}

A few "arrows" began to appear late in November and flowers emerged rapidly through December and slackened during the first weeks of January. The final flower count, taken December 27, was incorrectly based on the current plant population rather than on the number of plants mature enough to flower by late August. Consequently, the computed flowering percentages remained below 50 percent, a value considered low for the C.P. 5243 variety in this area.

Nonetheless, some degree of flower control was achieved by Paraquat, and a much greater degree by GA. The growth hormone was much more effective when applied alone than in combination with Si (table 1). Data presented in table 1 indicate that Paraquat reduced the flower percentage 
to about one-third of control levels. Flower production was nil in plants given GA alone regardless of whether Paraquat was received or not. The GA effect was significant at the 1-percent level when applied alone, and at the 5-percent level when combined with Si. Among Paraquat-treated plants neither GA nor Si produced statistically-significant effects. The fact that Si permitted greater flowering in certain GA-treated plots is attributed to a moderating effect of $\mathrm{Si}$ on the hormone's growth activity.

T.AnLe 2.-Growth responses of the sugarcane variely C.P. 52-49 to foliar. trealmenl with Paraqual, GA, and Sil

\begin{tabular}{|c|c|c|c|c|c|c|c|}
\hline \multirow[b]{2}{*}{$\begin{array}{c}\text { Data } \\
\text { classification }\end{array}$} & \multirow{2}{*}{$\begin{array}{c}\text { Experi- } \\
\text { ment } \\
\text { Number }\end{array}$} & \multirow{2}{*}{$\begin{array}{c}\text { Para- } \\
\text { quat } \\
\text { (pints/ } \\
\text { acre) }\end{array}$} & \multicolumn{4}{|c|}{ Treatment- } & \multirow[b]{2}{*}{ Mean } \\
\hline & & & Control & $\begin{array}{c}S i \\
(500 \\
\text { p.p.m. }\end{array}$ & $\underset{(0.01 \%)}{\mathrm{GA}}$ & $\underset{\text { plus }}{\mathbf{G A}}$ & \\
\hline \multirow[t]{2}{*}{$\begin{array}{r}\text { Green weight } \\
\text { (lbs./plant) }\end{array}$} & $\begin{array}{l}1 \\
2\end{array}$ & $\begin{array}{c}0 \\
0.5\end{array}$ & $\begin{array}{l}4.70 \\
4.01\end{array}$ & $\begin{array}{l}5.03 \\
4.19\end{array}$ & $\begin{array}{l}5.23 \\
4.05\end{array}$ & $\begin{array}{l}4.73 \\
4.48\end{array}$ & $\begin{array}{l}4.92 \\
4.18\end{array}$ \\
\hline & & Mean & 4.36 & 4.61 & 4.64 & 4.62 & \\
\hline \multirow[t]{2}{*}{$\begin{array}{l}\text { Stalk weight } \\
\text { (lbs./stalk) }\end{array}$} & $\begin{array}{l}1 \\
2\end{array}$ & $\begin{array}{c}0 \\
0.5\end{array}$ & $\begin{array}{l}3.30 \\
2.86\end{array}$ & $\begin{array}{l}3.73 \\
2.95\end{array}$ & $\begin{array}{l}3.80 \\
3.01\end{array}$ & $\begin{array}{l}3.59 \\
3.23\end{array}$ & $\begin{array}{l}3.61 \\
3.01\end{array}$ \\
\hline & & Mean & 3.08 & 3.34 & 3.41 & 3.41 & \\
\hline \multirow[t]{2}{*}{$\begin{array}{l}\text { Internode } \\
\text { length (in.) }\end{array}$} & $\begin{array}{l}1 \\
2\end{array}$ & $\begin{array}{c}0 \\
0.5\end{array}$ & $\begin{array}{l}4.6 \\
4.1\end{array}$ & $\begin{array}{l}4.8 \\
4.0\end{array}$ & $\begin{array}{l}5.1 \\
4.5\end{array}$ & $\begin{array}{l}4.8 \\
4.1\end{array}$ & $\begin{array}{l}4.8 \\
4.2\end{array}$ \\
\hline & & Mean & 4.4 & 4.4 & 4.8 & 4.5 & \\
\hline \multirow[t]{2}{*}{$\begin{array}{l}\text { Number of } \\
\text { internodes }\end{array}$} & $\begin{array}{l}1 \\
2\end{array}$ & $\begin{array}{c}0 \\
0.5\end{array}$ & $\begin{array}{l}13.3 \\
13.5\end{array}$ & $\begin{array}{l}13.1 \\
13.5\end{array}$ & $\begin{array}{l}12.6 \\
13.2\end{array}$ & $\begin{array}{l}12.7 \\
13.8\end{array}$ & $\begin{array}{l}12.9 \\
13.5\end{array}$ \\
\hline & & Mean & 13.4 & 13.3 & 12.9 & 13.3 & \\
\hline
\end{tabular}

1 Each figure represents the mean of six replicates. Ten uniform plants were harvested from each replicate.

It is quite clear that flowering control with GA, i.e., by preservation of the vegetative apical meristem, was totally effective. This justifies further investigation of flower control by hormonal means, and underscores the need to examine hormone roles and balances in sugarcane growth and development.

GROWTH RESPONSES TO PARAQUAT, GA, AND SI

Table 2 summarizes growth data for sugarcane given variable GA and $\mathrm{Si}$, with and without Paraquat superimposed as a single aerial treatment. 
Mean values for the two experiments show that, after 117 days, green weights, stalk weights, and internode lengths were all lessened in response to Paraquat. The Paraquat effect was consistent among the control, Si and GA-treated plants. In a cane population having 25,000 stalks per acre a green-weight loss of about 8.6 tons per acre, and a stalk-weight loss of 5.5 tons per acre, would have transpired as a consequence of Paraquat applied alone. Although this effect conforms to logic since Paraquat-treated cane was growing under the burden of a damaged top for more than a month, the tonnage effects did not attain statistical significance and no definite conclusions are drawn.

Cane treated with GA made definite gains with respect to green weight, stalk weight, and internode length, in addition to producing less flowers than those sprayed with Paraquat. Thus, the mean stalk weight for an average plant treated with GA was 3.80 pounds, as compared to 2.86 pounds for an average plant given Paraquat for flower control. On a basis of 25,000 plants per acre, this difference would amount to more than 11 tons of stalks per acre in favor of GA, with the added advantage that GA also achieved nearly complete flower control.

Surprisingly, foliar Si seemed to encourage growth as indicatea by green weights and stalk weights shown in table 2 . Although the tabulated values were not statistically significant, evidence of Si-stimulated growth has been reported elsewhere $(11,30)$. An increasingly complex series of $\mathrm{Si}$ roles in cane are being elucidated $(1,4,33)$. However, it was not suspected that cane would respond to the small amounts of Si received in a foliar spray, especially under the soil conditions prevalent in southern Puerto Rico. ${ }^{5}$ It is also evident that growth gains produced by GA and Si were largely cancelled by Paraquat. Putting this another way, foliar Si did not give sufficient protection against Paraquat for normal growth to continue. It has been shown, at the greenhouse level, that $\mathrm{Si}$ does give limited protection for sucrose-forming mechanisms sensitive to Paraquat (7).

With regard to internode length, the only treatment yielding greater values than controls was GA supplied alone (table 2). Paraquat suppressed internode length in each treatment group. The mean internode value for GA, 5.1 inches, is misleading since it represents the mean of all mature internodes laid down above internode number 7, i.e., the internode already visible when GA was applied. This constitutes some 12 to 14 internodes

${ }^{5} \mathrm{Si}$ appears to alleviate problems relating to manganese toxicity, insufficient calcium, low pH, and possibly insufficient available phosphorus. None of these were anticipated at Central Mercedita. Another function of Si recognized since this study was completed is a capacity to "buffer" against chemically-induced stress (7). It is possible that some sort of growth stresses were operative in the present control plants which in turn yielded to foliar Si. 
formed after treatments were initiated. In fact, no more than five or six of these were elongated by GA, the remainder more correctly belonged to a growth phase yielding internodes equal to or shorter than controls. This diphasic growth response to GA is illustrated by figure 1. Statistical analyses of individual internode lengths showed significantly greater elongation for joints 10-13, and significantly less clongation for joints 18-20 (fig. 1,A).
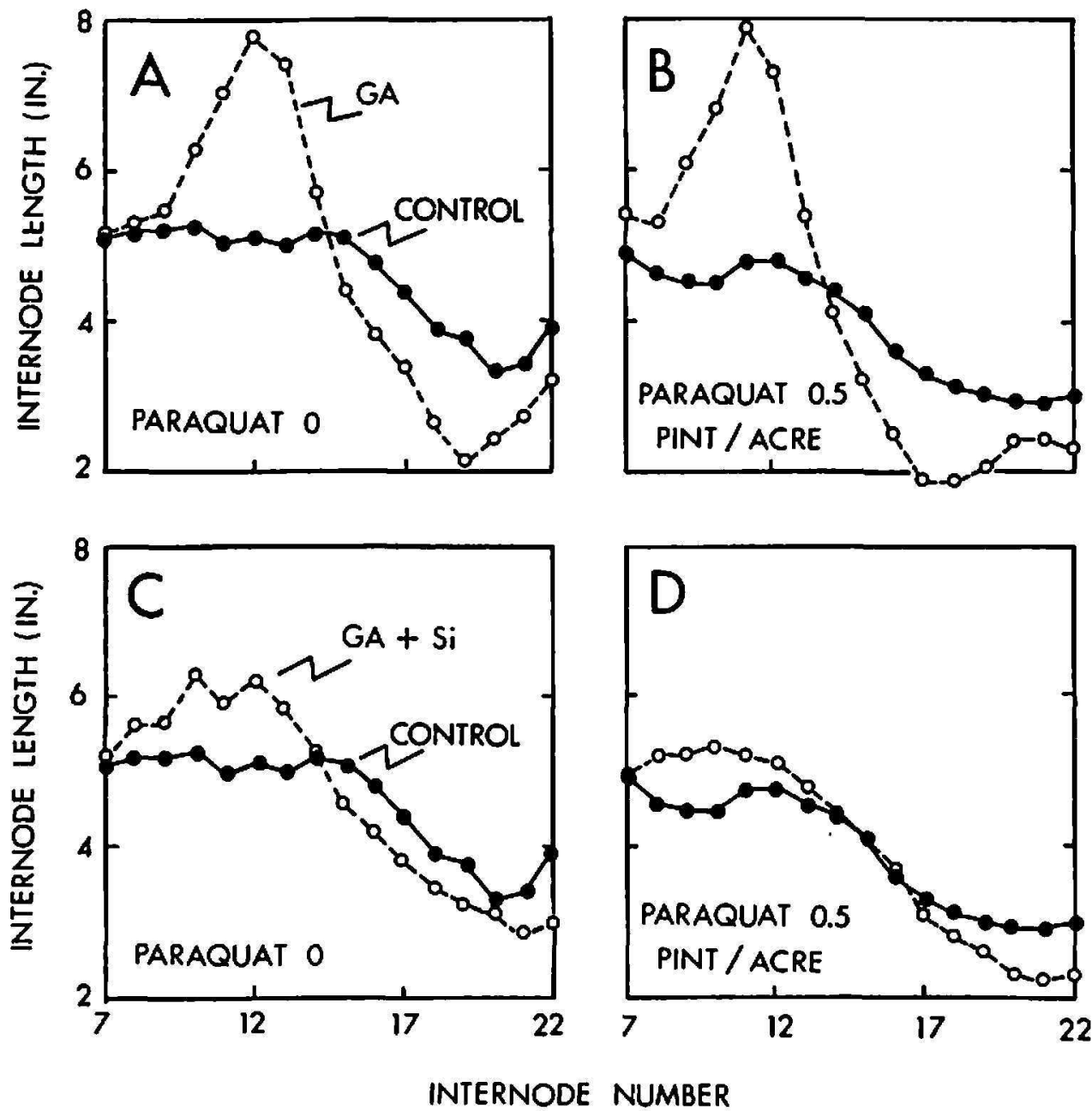

Fig. 1.-Lffects of GA, Si, and Paraquat on internode elongation of sugarcane: A, Temporary elongation increases followed by reversion to subnormal elongation in GA-treated plants; B, identical growth responses in plants treated with Paraquat shortly after receiving $\mathrm{GA} ; \mathrm{C}$, moderation of both growth stimulation and growth reversion by $\mathrm{Si}$ combined with $(\mathrm{iA} ; \mathrm{D}$, same as $\mathrm{C}$, with Paraquat also given.

Comparable results were obtained with Paraquat superimposed over the GA treatments (fig. 1,B). This is taken as evidence that GA does not require an undamaged canopy in performing its growth activity.

The regime of growth decline, or the "post-growth stimulatory phase", has been observed and investigated at the greenhouse level (6). In the authors' opinion it most correctly denotes a new growth regime, distinct 
either from that of control plants or from the pre-treatment period of GA plants. Harvested stalks showing the elongation differentials are illustrated in figure 2.

Although Paraquat did not change appreciably the distinct GA regimes of growth stimulation and growth decline, Si very strikingly alleviated both the growth-stimulatory and growth-reversionary phases (figs. 1,C and D). Neither phase produced statistically significant growth changes when $\mathrm{Si}$ was combined with GA. Typical stalk samples from the control, GA, and GA plus Si treatments are presented in figure 3. As noted briefly above, Paraquat suppressed internode elongation in the respective control plots,
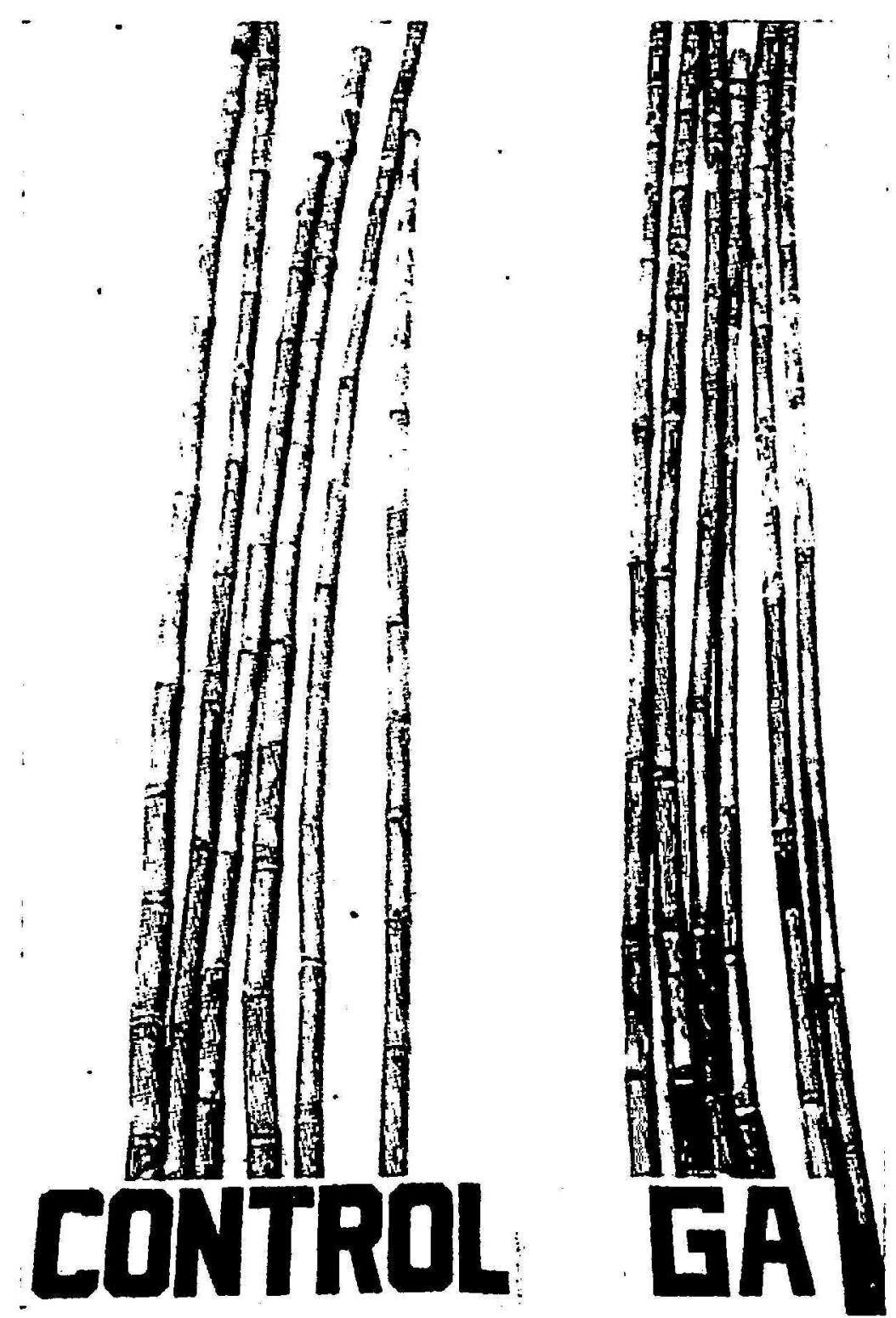

Fig. 2.-Differential elongation of internodes from GA-treated sugarcane as compared with controls. Elongation increased over a growth period encompassing about four internodes, and was followed by reversion to subnormal growth. 
i.e., those plots receiving neither GA nor $\mathrm{Si}$ (fig. 4). The most severe Paraquat effect was evident shortly after the chemical was applied (affecting internodes 8-10), but the reader will observe that normal elongation rates were not recovered even after the damaged leaves were fully replaced with green ones (corresponding approximately to internodes 11 or 12).

\section{CONTROL}

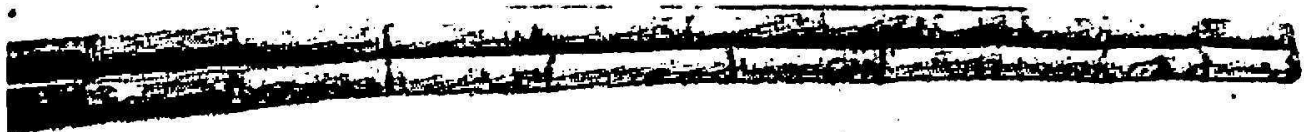

\section{GA}

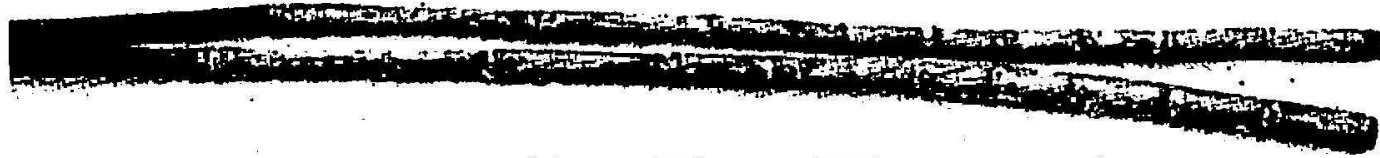

\section{GA+5i}

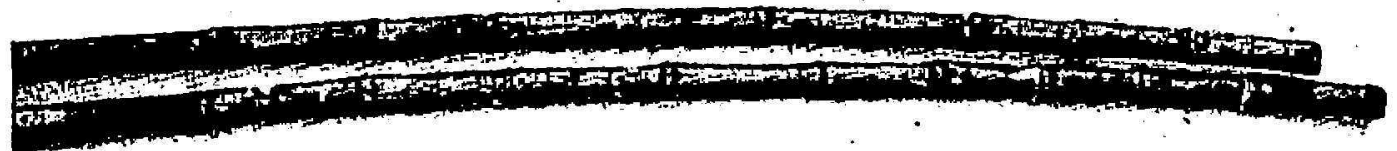

Fig. 3.-Differential elongation of internodes from sugarcane treated with GA and Si. Note subnormal expansion of internodes in stalks treated with GA alone, and a moderation or "buffering" of the growth reversion when Si was combined with GA.

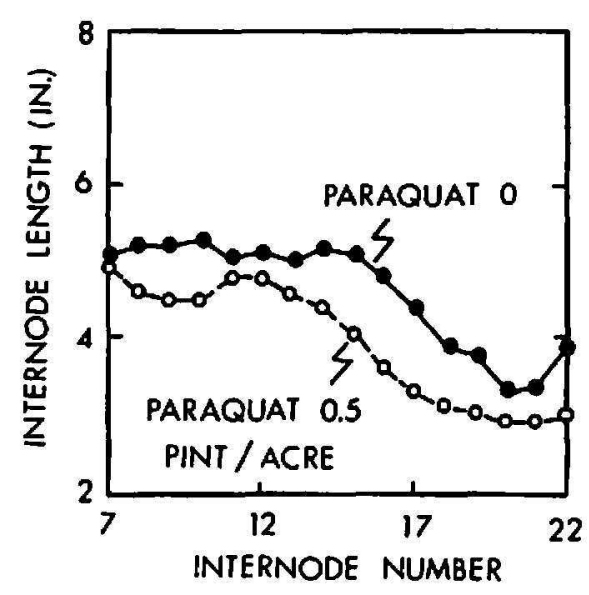

Fig. 4.-Suppression of sugarcane internode elongation by Paraquat applied at the rate of 0.5 pint per acre. 
Several implications arise once it is recognized that GA produces two growth regimes. First, the net growth gain from GA treatments must be equal to the total growth stimulation minus growth lost during the period of growth reversion. Failure to take both phases into account may explain some of the inconsistency of GA action reported in the literature. Second, since $\mathrm{Si}$ limits reversion as well as stimulation, it should be possible to strengthen the positive GA effect by delaying Si treatment until reversion is about to begin.

TABLE 3.-Brix and polarizalion values for milled juice of sugarcane trealed with foliar Paraqual, GA, and $S i^{3}$

\begin{tabular}{|c|c|c|c|c|c|c|c|}
\hline \multirow[b]{2}{*}{$\begin{array}{c}\text { Experiment } \\
\text { Number }\end{array}$} & \multirow[b]{2}{*}{$\begin{array}{l}\text { Data } \\
\text { class. }\end{array}$} & \multirow{2}{*}{$\begin{array}{l}\text { Days } \\
\text { after } \\
\text { treat. }\end{array}$} & \multicolumn{4}{|c|}{ Treatment- } & \multirow[b]{2}{*}{ Mean } \\
\hline & & & Con- & $\begin{array}{c}\mathrm{Si} \\
(500 \\
\text { p.p.m.) }\end{array}$ & $\begin{array}{c}\mathrm{GA} \\
(.01 \%)\end{array}$ & $\begin{array}{c}\text { Si } \\
\text { plus } \\
G A\end{array}$ & \\
\hline \multirow{10}{*}{$\begin{array}{l}1 \text { (Without } \\
\text { Paraquat) }\end{array}$} & \multirow[t]{5}{*}{ Brix } & 20 & 13.4 & 12.9 & 11.6 & 11.9 & 12.5 \\
\hline & & 55 & 15.8 & 15.5 & 17.5 & 16.5 & 16.3 \\
\hline & & 97 & 19.4 & 18.9 & 20.9 & 20.1 & 19.8 \\
\hline & & 139 & 19.4 & 19.2 & 19.9 & 19.6 & 19.5 \\
\hline & & Mean & 17.0 & 16.6 & 17.5 & 17.0 & \\
\hline & \multirow[t]{5}{*}{ Pol } & 20 & 36.7 & 35.4 & 28.2 & 27.9 & 32.1 \\
\hline & & 55 & 47.0 & 44.1 & 50.3 & 47.7 & 47.3 \\
\hline & & 97 & 67.4 & 65.3 & 75.3 & 70.0 & 69.5 \\
\hline & & $13 !)$ & 68.6 & 68.8 & 72.6 & 69.8 & 70.0 \\
\hline & & Mean & 54.9 & 53.4 & 56.6 & 53.9 & \\
\hline \multirow{10}{*}{$\begin{array}{l}2 \text { (With Para- } \\
\text { quat, } 0.5 \\
\text { pint/A.) }\end{array}$} & \multirow[t]{5}{*}{ Brix } & 20 & 12.4 & 12.8 & 12.0 & 11.7 & 12.2 \\
\hline & & 55 & 15.0 & 16.5 & 17.2 & 16.6 & 16.3 \\
\hline & & 97 & 19.8 & 19.8 & 20.2 & 19.9 & 19.9 \\
\hline & & 139 & 19.5 & 19.5 & 19.2 & 18.8 & 19.3 \\
\hline & & Mean & 16.7 & 17.2 & 17.2 & 16.8 & \\
\hline & \multirow[t]{5}{*}{ Pol } & 20 & 34.5 & 35.2 & 32.1 & 30.5 & 33.1 \\
\hline & & 55 & 44.4 & 46.0 & 48.3 & 48.6 & 46.8 \\
\hline & & 97 & 70.5 & 70.2 & 73.6 & 72.0 & 71.5 \\
\hline & & 139 & 69.6 & 69.5 & 67.9 & 65.9 & 68.3 \\
\hline & & Mean & 54.8 & 55.2 & 55.5 & 54.3 & \\
\hline
\end{tabular}

1 Values for the first three harvests represent aliquot samples from six combined replicates, with four stalks being taken from each replicate. Values for the final harvest represent the mean of six replicates with 10 stalks taken from each replicate. Statistical analyses were performed only with dat a from the final harvest. 


\section{sugar Responses to paraquat, Ga, AND SI}

As was true of flowering control and growth stimulation, GA given alone was the most effective treatment for altering sugar production. Although statistical analyses are available only for the final harvest, Brix and pol values show an apparent quality decline at the earliest harvest followed by improved juice quality at 55 and 97 days (table 3). A similar diphasic sugar response to applied GA has been reported in greenhouse-grown cane (10). The GA effect was most pronounced in the absence of Paraquat. In general, Paraquat produced moderate and temporary quality restrictions from which the plants later appeared to recover. Si, when applied alone, tended to counter early sucrose losses induced by Paraquat; when given in combination with GA it restricted the positive effect of GA on juice
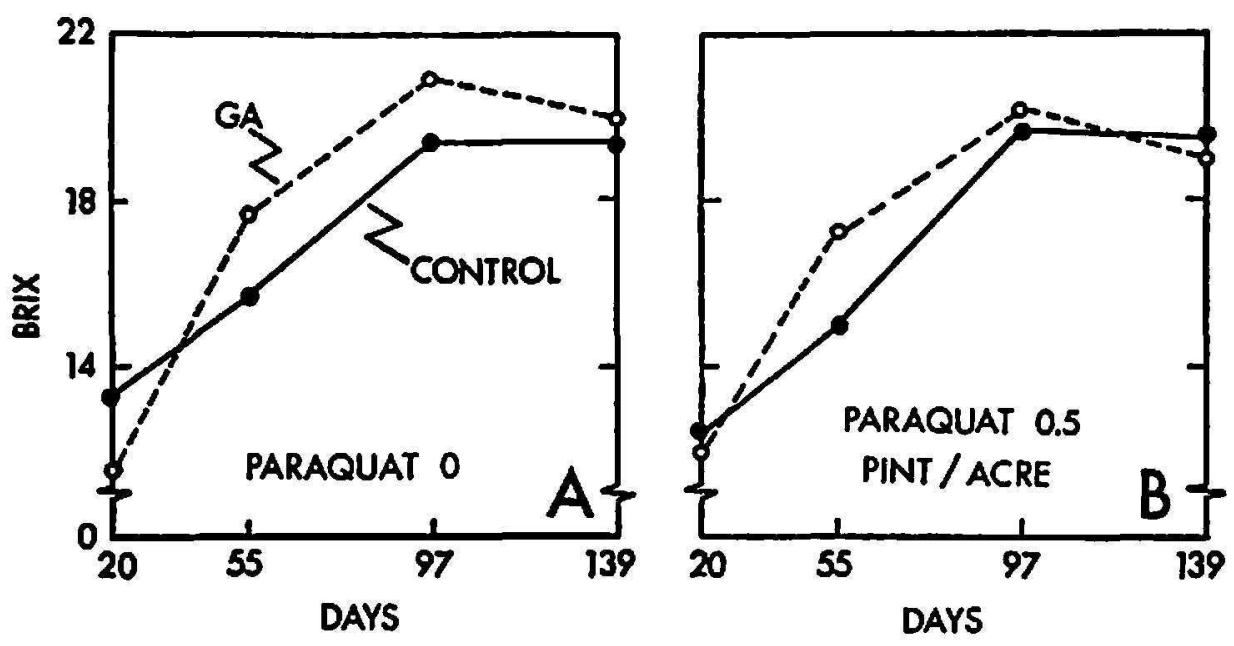

Fia. 5.-Effects of foliar GA on Brix values of milled juice: A, GA-increased Brix ralues for cane receiving no Paraquat; $B$, restriction of the GA effect by Paraquat given at the rate of 0.5 pint per acre.

quality. Si appeared to have a buffering effect against sugar changes corresponding to the effects already noted against growth changes.

As illustrated by figure 5, the early sugar losses caused by GA were made good sometime between the 20- and 55-day harvests. Figure 5,A shows that the positive GA effect was still active at 97 days, and that this effect was waning by 139 days. Paraquat tended to restrict both the degree and duration of sugar increase (fig. 5,B).

In a recent greenhouse study Alexander et al. (10) found that GA caused sucrose decline in those internodes already laid down at the time of application, but that within a few weeks the internodes of GA-treated cane began to accumulate more sucrose than control internodes. The net effect was a generally positive GA-sucrose relationship whose absolute expression depended upon the time interval between GA penetration and harvest. 
The present field data are consistent with this relationship. Early sugar decline would represent sucrose lost while the plant accelerated growth, and later accumulations in turn signify a new level of sugar synthesis which more than satisfies growth needs. Evidence of a GA-stimulated photosynthetic capability (9) and of GA-induced ripening action (10) has recently been published.

The GA- and Paraquat-induced sugar changes in milled juice correspond to leaf sucrose values recorded for the first three harvests (table 4, fig. 6).

TABLE 4.-Leaf sucrose content of sugarcane treated with foliar Paraqual, GA, and Si!

\begin{tabular}{|c|c|c|c|c|c|c|c|}
\hline \multirow{2}{*}{$\begin{array}{l}\text { Experi- } \\
\text { ment } \\
\text { Number }\end{array}$} & \multirow[b]{2}{*}{$\begin{array}{c}\text { Paraquat } \\
\text { (pints/acre) }\end{array}$} & \multirow{2}{*}{$\begin{array}{c}\text { Days } \\
\text { after } \\
\text { treatment }\end{array}$} & \multicolumn{4}{|c|}{ Sucrose, $\mathrm{mg} . / \mathrm{g} .$, for treatment- } & \multirow[b]{2}{*}{ Mean } \\
\hline & & & Control & $\begin{array}{c}\mathbf{S i} \\
(500 \\
\text { p.p.m.) }\end{array}$ & $\underset{(0.01 \%)}{\mathrm{GA}}$ & $\begin{array}{c}\text { Si } \\
\text { plus } \\
G A\end{array}$ & \\
\hline \multirow[t]{4}{*}{1} & $\mathbf{0}$ & 20 & 48.0 & 48.1 & $38.7^{*}$ & 45.0 & 45.0 \\
\hline & & 55 & 42.1 & 40.3 & $59.5^{* *}$ & 47.9 & 47.5 \\
\hline & & 97 & 43.2 & 42.0 & $64.7^{* *}$ & 46.8 & 49.2 \\
\hline & & Mean & 44.4 & 43.5 & 54.3 & 46.6 & \\
\hline \multirow[t]{4}{*}{2} & 0.5 & 20 & 44.2 & 50.0 & 43.2 & 44.2 & 45.4 \\
\hline & & 55 & 53.3 & 53.6 & 61.6 & 55.1 & 55.9 \\
\hline & & 97 & 63.1 & 55.6 & 57.9 & 58.8 & 58.9 \\
\hline & & Mean & 53.5 & 53.1 & 54.2 & 52.7 & \\
\hline
\end{tabular}

1 Each figure represents the mean of six replicates.

* Deviation from control is significant at the 5-percent level.

** Deviation from control is significant at the 1-percent level.
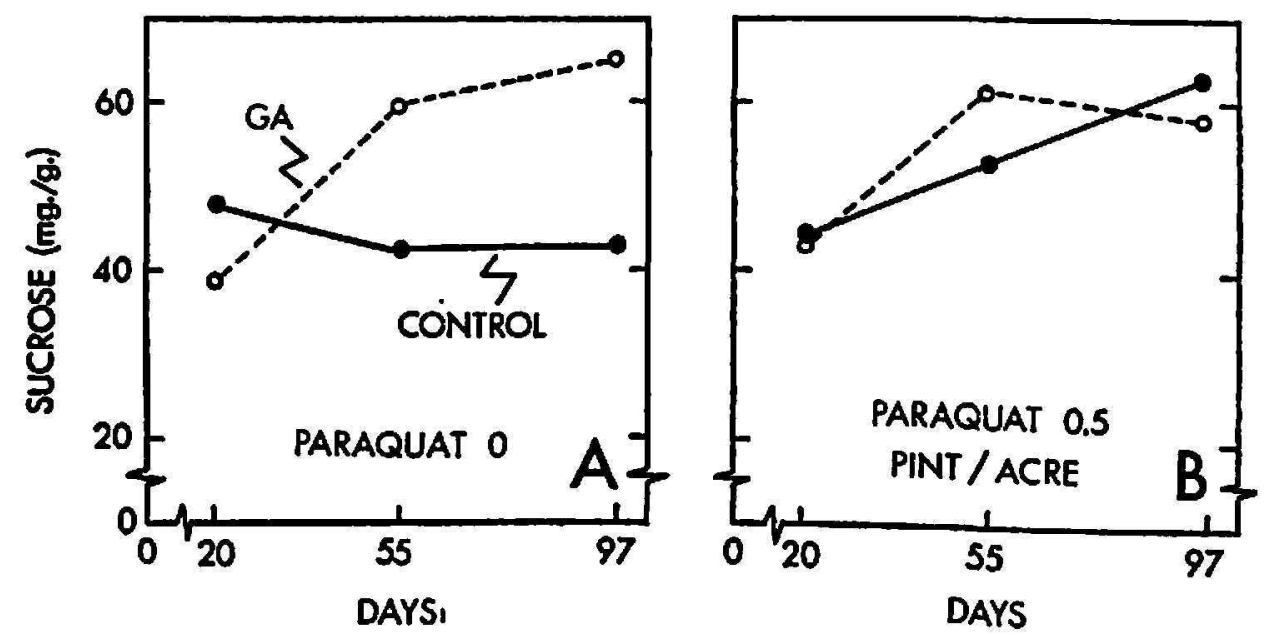

Fia. 6. -Effects of foliar GA and Paraquat on the leaf sucrose content of sugarcane: A, GA-induced sucrose increases in plants not sprayed with Paraquat; B, Paraquat restriction of the degree and duration of $\mathrm{GA}$-induced sucrose increases. 
Figure 6,A illustrates a positive effect of GA on leaf sucrose which developed between 20 and 55 days, and persisted until 97 days. Figure 6,B shows that Paraquat seriously restrained the GA action at 55 days and by 97 days Paraquat had removed the GA effect entirely. It thus appears that GA activity in sugar synthesis was far more sensitive to interference by Paraquat than was GA growth activity in internode expansion (figs. $1, \mathrm{~A}$ and $\mathrm{B}$ ).

It should be noted that this interpretation is based upon the respective control values for the two Paraquat experiments. If onc relied only upon the zero-Paraquat control curve, that is, if the control curve in figure 6,A were reproduced in figure $6, \mathrm{~B}$, it would be valid to say that Paraquat only moderated the GA increase of sucrose. This interpretation is not entirely erroneous but it is less accurate than conclusions drawn on the basis of

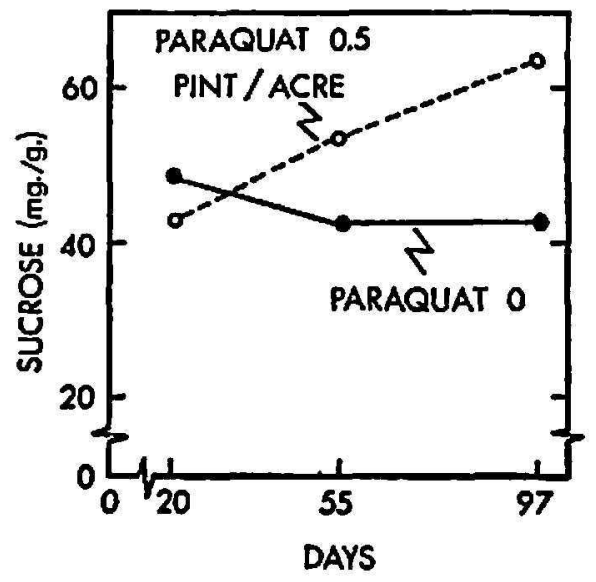

Fra. 7.-Increased sucrose content of sugarcane leaves during an extended time interval following treatment with foliar Paraquat.

distinct control groups. The essential point here is that Paraquat itself caused important sucrose changes regardless of whether GA was also present.

As illustrated by figure 7, there was a progressive improvement from 20 to 97 days in the sucrose-forming capability of control plants treated with Paraquat. For control plants not treated with Paraquat this capacity declined slightly during the same period. Paraquat has previously been shown to restrict sucrose synthesis in sugarcane $(2,3,5)$. It is possible that the stress imposed upon the mechanism of sugar synthesis induced a state of "overcompensation" when rebuilding the sugar-forming mechanism in a new green top. This theory was forwarded earlier (8) but could not be substantiated on the basis of relatively short-term greenhouse experiments.

It seems very possible that sugarcane will in fact recover much of its lost sugar-forming potential if sufficient time is allowed after Paraquat 
treatment. ${ }^{6}$ However, on the basis of the present study, there is no evidence that the sucrose recovery would be matched by a recovery of lost tonnage, nor does the reinvigorated sugar productivity match that which could have been attained with GA. Considering that GA also gave better flowering control as well as concurrent growth increases, the use of a tissue-destroying desiccant for cane flowering control appears to be a needlessly wasteful process.

\section{SUMMARY}

Sugarcane flower control studies were conducted with Paraquat, gibberellic acid (GA) and sodium meta-silicate ( $\mathrm{Si}$ ) applied as foliar sprays just prior to the period of floral initiation. The test clone, C.P. 52-43, blooms heavily in southern Puerto Rico and initiates flower primordia about September 10. The primary objective was to determine whether flowering could be prevented by physiologically removing the apical meristem, with a growth stimulant such as GA, rather than by destruction of the green top, as by treatment with a desiccant such as Paraquat. Secondary objectives included comparisons of growth and sugar responses to GA and Paraquat, and to determine whether $\mathrm{Si}$, believed to act as a buffer against physiological extremes, possessed anti-flowering activity.

Two experiments were conducted simultaneously in a field of 7 -months old, first-ratoon cane at Central Mercedita, Ponce. Each experiment was given identical spray applications of $\mathrm{GA}$ and $\mathrm{Si}$; in addition, one experiment received Paraquat superimposed over all plots shortly after the GA and $\mathrm{Si}$ applications were complete. Aqueous GA, 0.01 percent active material, was applied with knapsack sprayers to $1 / 1000$-acre plots in volumes equal to 300 gallons per acre. Si was similarly applied at the level of 500 p.p.m. Treatments also included GA and $\mathrm{Si}$ combined in one solution. Paraquat was applied by aircraft at the rate of 0.5 pint per acre in 8 gallons of water per acre. GA and Si treatments were given on August 22 and repeated on August 29. Paraquat was applied once on September 1.

The following results were obtained:

1. Flower counts taken on December 27 showed that GA given alone was the most effective treatment, reducing flowering rates to 0.02 percent. Paraquat reduced flowering to about one-third of control levels. Si had no effect by itself, but reduced the effectiveness of GA when the two agents were combined.

2. Total green weights, stalk weights, and internode lengths were increased by GA. Each parameter was decreased by Paraquat. Si given alone ap-

- When used as a preharvest desiccant no such time interval can be allowed for recovery of sugar potential. In achieving desiccation the sugar producer is thus faced with losses which the plant cannot compensate. 
peared to increase total green weight and stalk weight but the responses were not statistically significant. The primary effect of $\mathrm{Si}$ in combination with GA and Paraquat was to reduce the degree of growth stimulation by the hormone, and to lessen the growth suppression by the desiccant.

3. Sugar production was increased by GA and decreased by Paraquat. Paraquat also lessened the degree and duration of positive GA effects. Si had little effect on sugar as a lone entity but produced a buffering effect against relative sugar extremes as it did for growth extremes.

4. Early Paraquat injury to leaves, and hence to sugar-forming mechanisms, appeared to be more than compensated after about 2 months. Tonnage losses due to the foliar injury appeared to be permanent.

5. GA growth stimulation was followed by a reversion to less than normal growth. This growth reversion detracted from the total growth increases that otherwise might have been achieved. It was proposed that growth decline could be lessened with Si given as a delayed or follow-up treatment after GA.

6. Present evidence is consistent with the view that sugarcane flowering can be prevented more effectively by stimulating the apical meristem, at the critical period of flower initiation, than by destroying foliate essential for maximum growth and sugar production.

\section{RESUMEN}

Se realizaron estudios de control de la floración en la caña de azúcar mediante aspersiones foliares con Paraquat, ácido giberélico ( $\mathrm{AG}$ ) y metasilicato de sodio (Si), justamente antes de iniciarse el periodo de la floración. El clon con que se hicieron las pruebas fue el C.P. 52-43, que florece profusamente en la costa sur de Puerto Rico e inicia la formación de los primordios florales alrededor del 10 de septiembre. El objetivo primordial era determinar si se podía impedir la floración removiendo el meristemo apical con un estimulador de crecimiento como el $\mathrm{AG}$, en preferencia a la destrucción de la copa verde mediante tratamiento con un desecante tal como el Paraquat. Los objectivos secundarios inclúan una comparación entre el AG y el Paraquat en cuanto al ritmo de crecimiento y las variaciones que causaban en el contenido de azúcar, y una determinación respecto a si el $\mathrm{Si}$, el cual se cree actúa como un amortiguador frente a extremos fisiológicos, impedía la floración.

Se establecieron dos experimentos simultáneos en un predio de caña de primer retoño, de 7 meses de edad, en la Central Mercedita en Ponce. A cada parcela experimental se le hizo la misma aplicación foliar de AG y Si correspondiente; además, a todas las parcelas de uno de los experimentos se les aplicó Paraquat sobreimpuesto, poco después de completarse las aplicaciones de $\mathrm{AG}$ y $\mathrm{Si}$. Se aplicaron soluciones acuosas del compuesto activo de AG al 0.01 por ciento con asperjadores de mochila, a parcelas de 1/100 acre, a razón de 300 galones por acre. El Si se aplicó de igual manera a un nivel de 500 p.p.m. Los tratamientos incluyeron también una solución de AG y Si combinados. El Paraquat se aplicó por avión a razón de 0.5 pinta en 8 galones de agua por acre. Los tratamientos de AG y Si se aplicaron el 22 de agosto, repitiéndose ambos el 29 de agosto. Del Paraquat se hizo una sola aplicación el 1 de septiembre.

Se obtuvieron los siguientes resul tados. 
1. El contaje de flores que se hizo el 27 de diciembre demostró que el AG aplicado solo fue el tratamiento más efectivo, reduciendo la tasa de floración a 0.02 por ciento. El Paraquat redujo la floración a casi una tercera parte de los niveles registrados en el control. El Si por sí solo no tuvo ningún efecto, pero redujo la efectividad del AG cuando se combinaron los dos agentes.

2. El peso verde total, el peso de la caña molturable y la longitud del entrenudo aumentaron con el AG. El Paraquat disminuyó cada uno de los parámetros. La aplicación del Si solo pareció aumentar el peso verde total y el peso de la caña molturable aunque los resultados de su acción no fueron estadísticamente significativos. El efecto primordial del Si en combinación con el AG y el Paraquat fue reducir e] grado de estimulación del crecimiento causado por la hormona y disminuir la represión del crecimiento por el agente desecante. De este modo quedó comprobada la acción amortiguadora del Si en la caña.

3. El AG aumentó la producción de azúcar y el Paraquat la disminuyó. El Paraquat también disminuyó el grado y duración de los efectos positivos del AG. El Si por sí solo tuvo poco efecto en el azúcar, sin embargo actuó como un agente amortiguador frente a extremos relativos de azúcar, al igual que lo fue frente a extremos en el crecimiento.

4. El daño inicial del Paraquat a las hojas y por lo tanto a los mecanismos de la síntesis del azúcar, pareció quedar más que compensado después de unos 2 meses. Las pérdidas en el tonelaje debidas a las lesiones en el follaje parecieron ser irremediables.

5. La estimulación del crecimiento por el AG fue seguida por una reversión a un nivel menor al del crecimiento normal. Esta reversión en el crecimiento disminuyó el ritmo en el crecimiento total que muy bien pudiera haberse logrado. Se propuso que esta reversión en el crecimiento podría disminuirse mediante una aplicación tardía de Si o simplemente posterior al AG.

6. La evidencia que existe cuadra con el concepto de que la floración de la caña puede evitarse más efectivamente estimulando el meristemo apical durante el periodo crítico de la iniciación floral, antes que destruyendo el follaje esencial para un máximo crecimiento y producción de azúcar.

\section{LITERATURE CITED}

1. Alexander, A. G., In vitro effects of silicon on the action patterns of sugarcane acid invertases, J. Agr. Univ. P.R. 52 (4): 311-22, 1968.

2. Alexander, A. G., and Montalvo-Zapata, R., Enzyme studies of sucrose decline in sugarcane desiceated with Paraquat, J. Agr. Univ. P.R. 53 (4): 230-50, 1969.

3. Alexander, A. G., The potential of sugarcane to produce sucrose, Proc. Int. Soc. Sugar Cane Technol. 13: 1-24, 1969.

4. - In vitro effects of silicon on hydrolytic and oxidative enzymes of sugarcane, Proc. Int. Soc. Sugar Cane Technol. 13: 532, 1969.

5. Alexander, A. G., and Montalvo-Zapata, R., Enzymatic factors in the sucrose decline of sugarcane desiccated with Paraquat, Diquat, and Dinitrobutylphenol, J. Agr. Univ. P.R. 54 (1): 28-49, 1970.

6. Alexander, A. G., Montalvo-Zapata, R., and Kumar, A., Enzyme-silicon studies of gibberellic acid-treated sugarcane during the post growth-stimulatory phase, J. Agr. Univ. P.R. 54 (1): 82-95, 1970.

7. Alexander, A. G., and Montalvo-Zapata, R., The use of silicon to preserve sucrose in sugarcane desiccated with Paraquat and Diquat, J. Agr. Univ. P.R. 54 (2): 247-63, 1970. 
8. - Relationships of light to enzyme and sucrose transformations in sugarcane treated with Paraquat, J. Agr. Univ. P.R. 54 (2) : 264-96, 1970.

9. Alexander, A. G., Kumar, A., Montalvo-Zapata, R., and Spain, G. L., Response of sugarcane enzymes to variable light: Variable illumination studies of invertase, ATP-ase, and amylase in plants experiencing nitrate- and gibberellic acidinduced stress, J. Agr. Univ. P.R. 54 (3) : 448-76, 1970.

10. Alexander, A. G., Montalvo-Zapata, R., and Kumar, A., Gibberellic acid activity in sugarcane as a function of the number and frequency of applications, $J$. Agr. Univ. P.R. 54 (3) : 477-503, 1970.

11. Ayres, A. S., Calcium silicate slag as a growth stimulant for sugarcane on lowsilicon soils, Soil Sci. 101 (3) : 216-27, 1966.

12. Breeman, J. F., Liu, L. J., Ellis, T. O., and Arcenaux, G., Effect of elevation on arrowing and pollen fertility in sugarcane, Proc. Int. Soc. Sugar Cane Technol. 11: 540-5, 1962.

13. Burr, G. O., The flowering of sugarcane, Haw. Sugar Technol. Rept. 9: 47-9, 1950.

14. Burr, G. O., Hartt, C. E., Brodie, H. W., Tanimoto, T., Kortschak, H. P., Takahashi, D., Ashton, F. M., and Coleman, R. E., The sugarcane plant, Ann. Rev. Plant Physiol. 8: 275-308, 1957.

15. Cardini, C. E., Leloir, L. F., and Chiriboga, J., The biosynthesis of sucrose, J. Biol. Chem. 214: 149-55, 1955.

16. Chu, T. L., and Serapión, J. L., Flower initiation and tassel emergence in sugarcane, J. Agr. Univ. P.R. 55 (1): 101-113, 1971.

17. Clements, H. F., and Awada, M., Factors affecting the flowering of sugarcane, Ind. J. Sugar Res. Dev. 8: 140-59, 1964.

18. - Multiple top in sugarcane, Haw. Farm. Sci. 9: 1-13, 1960.

19. Coleman, R. E., Leaf and spindle-trimming effects on tasseling, Ann. Rept. Exp. Sta. Haw. Sugar Plant. Assn., p. 9, 1963.

20. - - Effects of temperature on flowering in sugarcane, Int. Sugar J. 65: 451-3, 1963.

21. Coleman, R. E., and Tanimoto, T., Chemicals are appraised for tassel control, Rept. Exp. Sta. Haw. Sugar Plant. Assn., p. 1, 1964.

22. - Tassel control, Rept. Exp. Sta. Haw. Sugar Plant. Assn., p. 10, 1965.

23. Coleman, R. E., Night, light, and tasseling, Rept. Exp. Sta. Haw. Sugar Plant. Assn., pp. 10-11, 1965.

24. - Physiology of flowering in sugarcane, Proc. Int. Soc. Sugar Technol., 13: 992-1,000, 1969.

25. Davies, W. N., and Barnes, T. R., Investigations on the incidence of pithiness in sugarcane and the effect of pithiness on jiice quality and fibre content, Ann. Rept. Tate \& Lyle Agr. Res. Sta., pp. 98-99, 1966.

26. George, E. F., Factors affecting the initiation of flowering in sugarcane, Rev. Agr. et Sucriere ile-Maurice 29: 328-40, 1960.

27. Heinz, D. J., Personal communication with the senior author, 1968.

28. Humbert, R. P., Lima, L. G., and Goveas, J., Trssel control progress with Reglone in the Mexican sugar industry, Proc. Int. Soc. Sugar Cane Technol. 13: 462-7, 1969.

29. James, N., Graduated delay of flowering in sugarcane with 11.5 hour dark periods, Proc. Int. Soc. Sugar Cane Technol. 13: 984-91, 1969.

30. Okuda, A., and Takahashi, E., The role of silicon. From: The mineral nutrition of the rice plant. Sym. Int. Rice Res. Inst., Johns Hopkins Press, Baltimore, Md., pp. 123-46, 1964. 
31. Panje, R. R., and Schrinivasan, K., Studies in Saccharum spontaneum. A note on the flowering sequence of Saccharum spontaneum clones, Proc. Int. Soc. Sugar Cane Technol. 10: 819-24, 1959.

32. Personal communication with Mr. T. L. Chu, Associate Plant Breeder, Gurabo Substation, Agr. Exp. Sta., Univ. P.R., Río Piedras, P.R., 1969.

33. Samuels, G., and Alexander, A. G., Influence of variable manganese and silicon on the nutrition, sugar production, and enzyme activity of immature sugarcane, Proc. Int. Soc. Sugar Cane Technol. 13: 544-55, 1969.

34. Sartoris, G. B., The behavior of sugarcane in relation to length of day, Proc. Int. Soc. Sugar Cane Technol. 6: 796-801, 1939.

35. Stehle, H., Intensity and seasons at which sugarcane flowers in relation to sucrose content and purity of juices, Proc. British West Indies Sugar Technol., pp. 58-62, 1955.

36. Tió, M. A., and González, P., Personal communication with the Director, Agr. Exp. Sta., Univ. P.R., 1951.

37. Tio, M. A., Photoperiodism responses of sugareane in Puerto Rico. Thesis submitted to the faculty of the graduate school in partial fulfillment of the requirements for the degree of Doctor of Philosophy, Pennsylvania State College, 1952.

38. Yussuf, $H$. D., and Dutt, R. L., Photoperiod in relation to the flowering of sugarcane, Cur. Sci. 14: 304-5, 1945. 